\title{
RANCANG BANGUN IKLAN WEB MOBILE MSGLOW MENGGUNAKAN GOOGLE WEB DESIGNER
}

\author{
Dhevin Kawistoro Ngabekti ${ }^{1}$, Anung Rachman ${ }^{2}$ \\ Institut Seni Indonesia Surakarta \\ Jalan Ki Hadjar Dewantara No.19, Kentingan, Kota Surakarta, Jawa Tengah. Telp (0271) 647658 \\ Email : dhevinkawistorongabekti@gmail.com, anung@isi-ska.ac.id
}

\begin{abstract}
ABSTRAK
Tidak dapat dipungkiri Periklanan menjadi cara yang esensial bagi perusahaan dalam memberikan informasi persuasif untuk membeli dan menyewa produk atau jasa yang dipasarkan untuk audiens. Terdapat berbagai macam media yang dapat digunakan untuk beriklan salah satunya adalah media internet. Pada saat ini internet menjadi media yang banyak digunakan sebagai media periklanan karena jangkauannya luas dan biayanya yang murah. Maka dari itu pemanfaatan penggunaan media internet untuk beriklan harus dimaksimalkan dengan cara membuat iklan menjadi lebih menarik dalam segi visual maupun penulisan. Hal ini dapat diatasi dengan adanya Google web designer yang merupakan aplikasi gratis yang dikembangkan oleh google untuk membuat iklan web mobile. Dalam penulisan jurnal ini peneliti akan merancang dan membuat iklan web mobile yang nantinya akan menggunakan produk skincare MSGlow dan MSGlow Men sebagai objek utama pembuatan iklan. Iklan web mobile ini akan dirancang menggunakan metode design sprint yang diharapkan dapat membantu untuk memudahkan dan membuat perancangan iklan web mobile menjadi lebih efisien.
\end{abstract}

Kata kunci: Iklan, Web, Mobile, Skincare

\section{ABSTRACT}

This is undeniable that advertising is an essential way for companies to provide persuasive information to buy and rent products or services that are marketed to an audience. There are various kinds of media that can be used to advertise, one of which is the internet. At this time the internet has become a medium that is widely used as an advertising because of its wide reach and low cost. Therefore, the use of internet media to advertise must be maximized by making advertisements more attractive in terms of visuals and writing. This can be overcome with the Google web designer which is a free application developed by Google to create mobile web ads. In writing this journal, researchers will design and create a mobile web ad that will use MSGlow and MSGlow Men skincare products as the main object of making advertisements. This mobile web ad will be designed using the design sprint method which is expected to help to simplify and make the design of mobile web ads more efficient.

Keywords: Ads, Web, Mobile, Skincare

\section{PENDAHULUAN}

Era digitalisasi saat ini membuat dunia bisnis mengalami perkembangan yang sangat pesat. Hal ini disebabkan perkembangan teknologi internet yang sangat pesat menyebabkan banyak perubahan dalam cara berkomunikasi. Tentu saja hal itu pun juga mempengaruhi suatu perusahaan dalam memasarkan dan mempromosikan produknya kepada khalayak ramai yaitu dengan cara iklan. Iklan merupakan suatu cara dalam menyajikan suatu gagasan mengenai barang dan jasa yang mana akan dibiayai oleh sponsor yang sifatnya tidak personal (Tyas \& Aryani, 2017). Iklan dapat diartikan bahwa sebuah komunikasi nonpersonal yang disampaikan melalui media massa yang bersifat berbayar, bersifat membujuk, dan membutuhkan sponsor. Perusahaan harus jeli, pintar dan cermat membuat kebijakan- kebijakan strategis baru dalam menjual produk dan jasa mereka dalam kaitannya menghadapi persaingan yang ketat dengan competitor. Karena pada dasarnya dengan adanya kompetitor maka akan banyak pilihan bagi pelanggan dalam memilih 
produk yang sesuai dengan harapanya. Oleh karena itu perusahaan memerlukan strategi jitu dalam memperebutkan pelanggan sekaligus dapat membuat pelanggan menjadi loyal dan setia terhadap perusahaan (Mayangsari \& Agustin, 2017).

Perusahaan juga harus mampu dalam memutuskan media yang akan dipakai untuk beriklan, keputusan tersebut yang juga nantinya akan digunakan untuk mempererat hubungan perusahaan dengan audiensnya. Internet menjadi alternatif media beriklan dengan biaya yang murah dan dapat menjangkau audiens secara luas. Terdapat banyak bentuk iklan yang terdapat di internet salah satunya adalah iklan web. Pembuatan iklan web ini dapat dilakukan menggunakan aplikasi Google Web Designer. Google web designer merupakan aplikasi gratis yang digunakan untuk membuat iklan web dengan berbagai varian format dan dapat dibuat secara praktis dan menarik.

Terdapat berbagai macam produk yang menggunakan format iklan web ini, salah satunya yaitu produk skincare. Skincare berasal dari Bahasa Inggris, yaitu skin yang berarti kulit dan care berarti perawatan, sehingga jika digabungkan berarti perawatan kulit. Dalam cakupan yang lebih luas, skincare dapat diartikan pula sebagai serangkaian praktik perawatan yang mendukung integritas kulit, meningkatkan penampilan dan meringankan kondisi kulit. Skincare yang diakukan secara teratur dan intensif tersebut dapat disebut dengan skincare routine ( et al., 2018). Peneliti memilih produk ini karena pengguna dan target market untuk produk skincare ini sebagian besar adalah anak muda sampai dewasa yang mana tidak asing dan sering menelusuri internet setiap harinya sehingga jangkauan iklan kepada audiens menjadi lebih efektif.

\section{KAJIAN PUSTAKA}

\subsection{Iklan}

Didalam iklan terdapat unsur komunikasi yang bersifat luas, yang mana berbeda dengan cara komunikasi pada umumnya yang berlangsung secara tatap muka dan terbilang pribadi. Komunikasi dalam iklan tidak bersifat secara langsung. Dalam hal ini, komunikator yang berupa iklan menyampaikan informasi tidak bertatap muka, tetapi menggunakan media atau sarana komunikasi yang bersifat luas. Maka dari itulah, komunikator atau pembuat iklan harus menyajikan informasi yang penyampaiannya menarik, mudah dipahami dan dapat menimbulkan efek persuasi bagi audiens (Nursalim, 2014).

Sedangkan menurut (Nabella, 2017) yang tertulis dalam jurnalnya definisi Iklan merupakan bentuk komunikasi yang bersifat massa atau luas, yang mana dilakukan oleh pengiklan (advertiser) untuk mengkomunikasikan informasi kepada konsumen (decoder) lewat berbagai media (channel). Iklan adalah berbagai bentuk aktivitas yang berbentuk komunikasi berguna untuk menyajikan dan mempromosikan barang, jasa dan ide, secara nonpersonal yang nantinya dibayar oleh sponsor yang terkait. Pada umumnya, iklan dibagi menjadi Iklan komersial, dan Iklan Layanan Masyarakat (ILM). Iklan komersial disebut juga iklan bisnis, yang bertujuan untuk memperoleh keuntungan berupa materi ekonomi dengan menawarkan barang ataupun jasa. Sedangkan Iklan Layanan Masyarakat (ILM) merupakan bagian dari kampanye yang mengarah kepada sosial marketing dengan tujuan menjual konsep ide atau gagasan diperuntukan terhadap kepentingan dan pelayanan masyarakat. Pesan yang terdapat di Iklan Layanan Masyarakat biasanya berupa himbauan atau ajakan, terhadap masyarakat dan khalayak ramai untuk melarang atau menganjurkan suatu kegiatan demi kebaikan bersama oleh semua pihak.

\subsection{Web}

Web dalam jurnal yang ditulis oleh (Susilo, 2018) memiliki definisi sebagai suatu layanan yang menyajikan informasi dengan menerapkan penggunaan konsep hyperlink (tautan), yang mana mempermudah para user atau pemakai komputer yang melakukan kegiatan browsing dan penelusuran informasi menggunakan internet. Web memiliki keistimewaan yang mana telah menjadikan web sebagai layanan yang mengalami pertumbuhan yang paling cepat. Web juga memberikan fitur highlight atau penyorotan pada kata-kata dan media gambar dalam suatu dokumen untuk menghubungkan, atau mengarah ke media yang lain seperti suara, dokumen, film. Web juga dapat menghubungkan pengguna internet dari berbagai tempat dalam sebuah dokumen atau gambar ke media tertentu yang bertempat di dokumen lain. Dengan browser yang mempunyai fitur Grapihcal User Interface (GUI), hanya dengan menekan mouse link-link dapat di hubungkan ke tujuannya. 


\subsection{Web Mobile}

Menurut Jurnal yang ditulis oleh (Hakim \& Vida, 2017) tercantum Web Mobile memiliki pengertian halaman website yang ada di internet yang digunakan dan di akses pada perangkat mobile.

\section{METODE PENELITIAN}

\subsection{Design Sprint}

Design sprint yang merupakan metodologi desain yang dikembangkan oleh Google untuk menyelesaikan masalah dengan melibatkan pengguna melalui perancangan, pembuatan prototype, dan pengujian ide dengan cepat. Metode ini digunakan kare na adanya urgensi waktu pembuatan prototype yang singkat atau cepat Dalam proses evauasi dan perancangannya akan menerapkan beberapa tahapan (Ramadan et al., 2019). Terdapat enam tahap dalam melakukan metode design sprint ini yaitu:

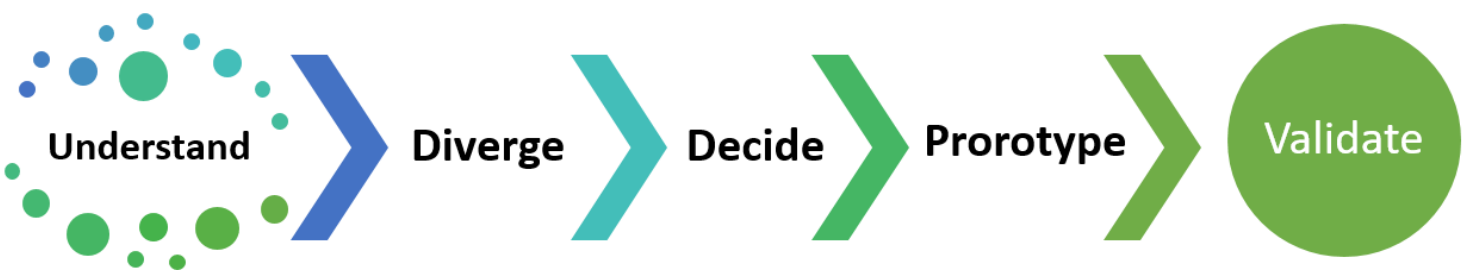

\section{Gambar 1. Enam Tahapan Metode Design Sprint}

Tahapan metode design sprint ini ada 5 yaitu :

1)Understand pada tahap ini ditentukan apa kebutuhan pengguna dan teknologi apa yang cocok untuk diimplementasikan. Ditahap ini dilakukan observasi terhadap pengguna tentang masalah yang terjadi pada pengguna dan penting memahami apa yang dialami oleh pengguna. Dalam penelitian perancangan kali ini peneliti menggunakan aplikasi google web designer yang maka dari itu peneliti harus mehamami dan mempelajari aplikasi yang akan digunakan sebagai alat untuk merancang iklan web mobile.

2)Diverge setelah melakukan tahap understand, hal selanjutnya yang dilakukan adalah mencari solusi dan membuat sketsa dari rancangan iklan web mobile yang akan dibuat menurut permasalahan yang diperoleh dari data pada tahap pertama. Pada tahap ini pengembangan ide merupakan hal yang utama untuk pembuatan dan strategi yang akan diterapkan dalam iklan.

3)Decide pada tahap ini menentukan solusi yang tepat dari permasalahan yang terjadi. Penentuan solusi ini dipilih dari berbagai ide, sketsa, dan rancangan yang telah dibuat dari ide yang sebelumnya. Pada tahap ini Peneliti memutuskan akan membuat iklan web mobile skincare ber merk MSGlow dengan menggunakan aplikasi Google Web Designer Keputusan ini sangat penting karena akan diterapkan pada tahap selanjutnya yang berupa prototype.

4)Prototype selanjutnya membuat suatu bentuk fisik dari suatu ide atau solusi yang dipilih baik berupa catatan yang dipasang di dinding, objek, atau storyboard. Dalam pembuatan iklan web mobile peneliti ingin membuat prototype iklan web mobile dengan objek Skincare menggunakan format iklan web Paralaks menggunakan aplikasi google web designer. Paralaks adalah format display berdampak tinggi yang menawan dan imersif untuk web seluler. Saat pengguna men-scroll halaman web, gambar di latar depan dan latar belakang bergerak pada kecepatan yang berbeda-beda, sehingga membentuk persepsi kedalaman. Dengan menggunakan format paralaks ini dapat diharapkan dapat lebih menarik perhatian audiens.

5) Validate Masuk pada tahap validate, di mana prototype yang telah dikembangkan sebelumnya akan di review dengan menggunakan usability testing berdasarkan aspek parameter yang akan dicapai yaitu efisiensi, efektivitas, dan kepuasan pengguna terhadap kebutuhan dengan fungsi utama. Pada tahap terakhir ini dilakukan uji coba kepada pengguna dari protoype yang dibuat., Pengujian ini selain ditujukan untuk pengguna bisa juga ditujukan untuk audiens dengan target segmentasi dan pasar yang sudah direncanakan atau kepada seseorang yang ahli pada bidang tersebut. 


\section{PEMBAHASAN}

Peneliti akan menggunakan metode perancangan design sprint yang akan digunakan untuk pembuatan kedua iklan web mobile MSGlow dan MSGlow men yang akan dibuat di aplikasi Google Web Designer

\subsection{Understand}

Berdasarkan pemahaman dan hasil yang ditemukan pada tahapan pertama, dalam perancangan dan pembuatan iklan web perlu adanya komposisis yang menarik dalam segi gambar, Typography, Copywriting dan layout. Tidak hanya itu iklan harus dibuat seefektif mungkin agar pesan yang disampaikan mudah dipahami dan tidak menimbulkan rasa gangguan kepada audiens. Selain itu peneliti juga sudah memahami segmentasi pasar yang berkaitan dengan brand iklan yang akan dibuat yaitu MSGlow yang merupakan banyak dan sebagian besar pasar nya mengarah kepada Usia Remaja sampai Dewasa 17 - 30. Namun dalam pembuatan iklan web diperlukan adanya pemahaman dan penguasaan aplikasi Google Web Designer

\subsection{Diverge}

Setelah memahami dan melakukan riset mengenai iklan web maupun produk yang akan diiklankan. Pada tahapan ini peneliti akan membuat sketsa yang bisa dilihat dari gambar dibawah ini

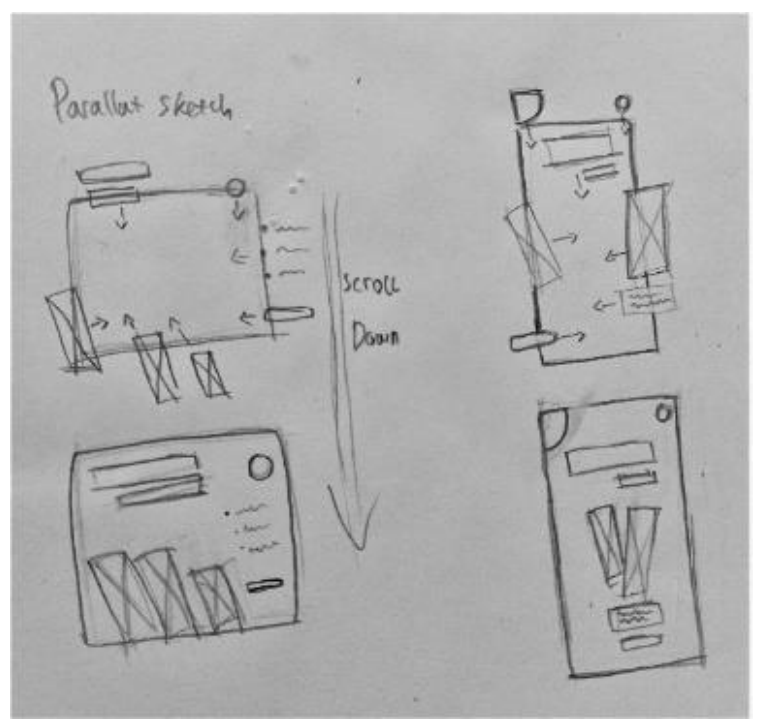

\section{Gambar 2. Sketsa Iklan web mobile MSGlow}

Gambar diatas merupakan 2 Rancangan iklan web yang berdimensi 300 x 250 pixel untuk produk MSGlow Men dan yang satu berdimensi 300 x 600 pixel Untuk MSGlow.

\subsection{Decide}

Pada tahapan ini setelah peneliti membuat sketsa tahapan selanjutnya membuat komponen komponen iklan. Dalam pembuatan komponen iklan ini membutuhkan beberapa aplikasi tambahan yaitu Photoshop untuk mengedit foto produk dan Adobe Illustrator untuk membuat dan menyusun kembali komponen komponen tambahan yang antara lain : Ornamen, Gambar, Typography, Background dan elemen pendukung lainya. Komponen - komponen dalam pembuatan iklan ini pun dapat dilihat melalui gambar dibawah 


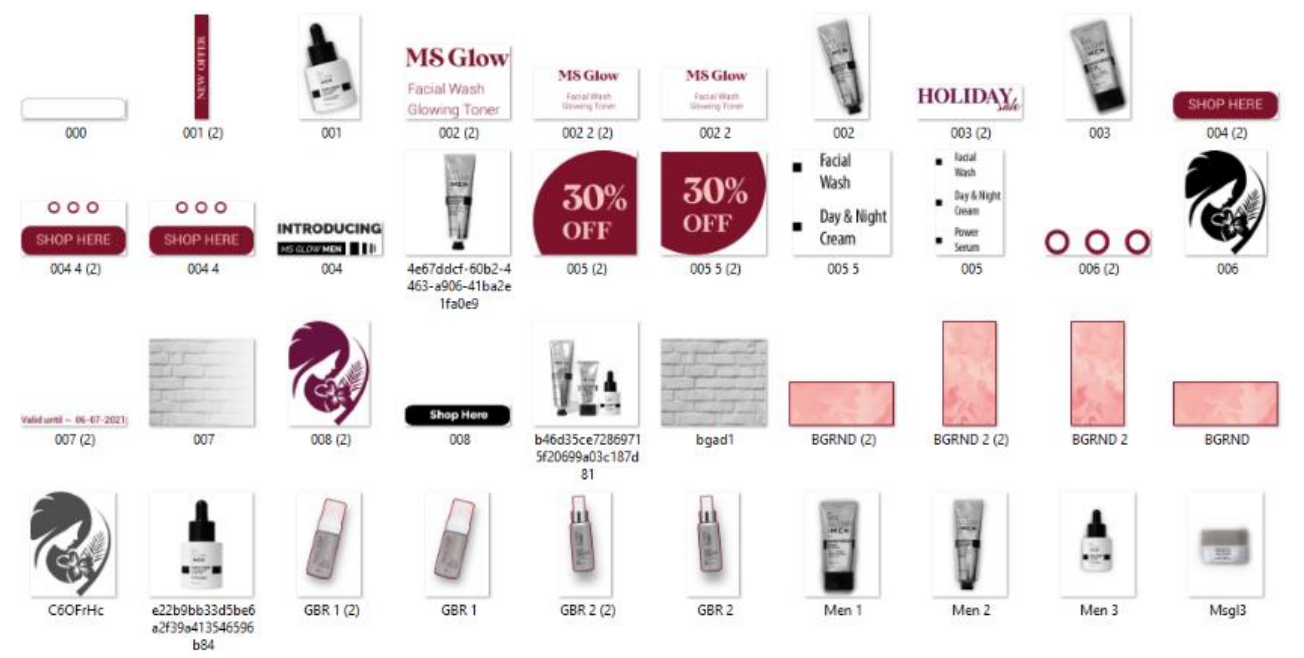

Gambar 3. Komponen Pembuatan 2 Iklan Web mobile MSGlow

Gambar diatas merupakan Komponen - komponen yang diperlukan dalam pembuatan iklan berdasarkan 2 rancangan sketsa iklan dan selanjutnya akan dirangkai dan dibuat menjadi iklan web melalui aplikasi Google Web Designer. Pada pembuatan iklan ini peneliti memutuskan untuk menggunakan format paralaks yang mana saat pengguna men-scroll halaman web, gambar di latar depan dan latar belakang bergerak pada kecepatan yang berbeda-beda, sehingga membentuk persepsi kedalaman. Dengan menggunakan format paralaks ini dapat diharapkan dapat lebih menarik perhatian audiens.

\subsection{Prorotype}

Setelah membuat rancangan sketsa dan komponen untuk pembuatan iklan web mobile, langkah selanjutnya yaitu melakukan tahapan pembuatan iklan web mobile melalui aplikasi Google Web Designer. Pada tahapan kali ini peneliti akan membuat, merangkai dan menyusun semua komponen yang sudah ditentukan dan menggunakan format paralaks yang nantinya akan menjadi iklan web mobile seperti gambar dibawah ini.

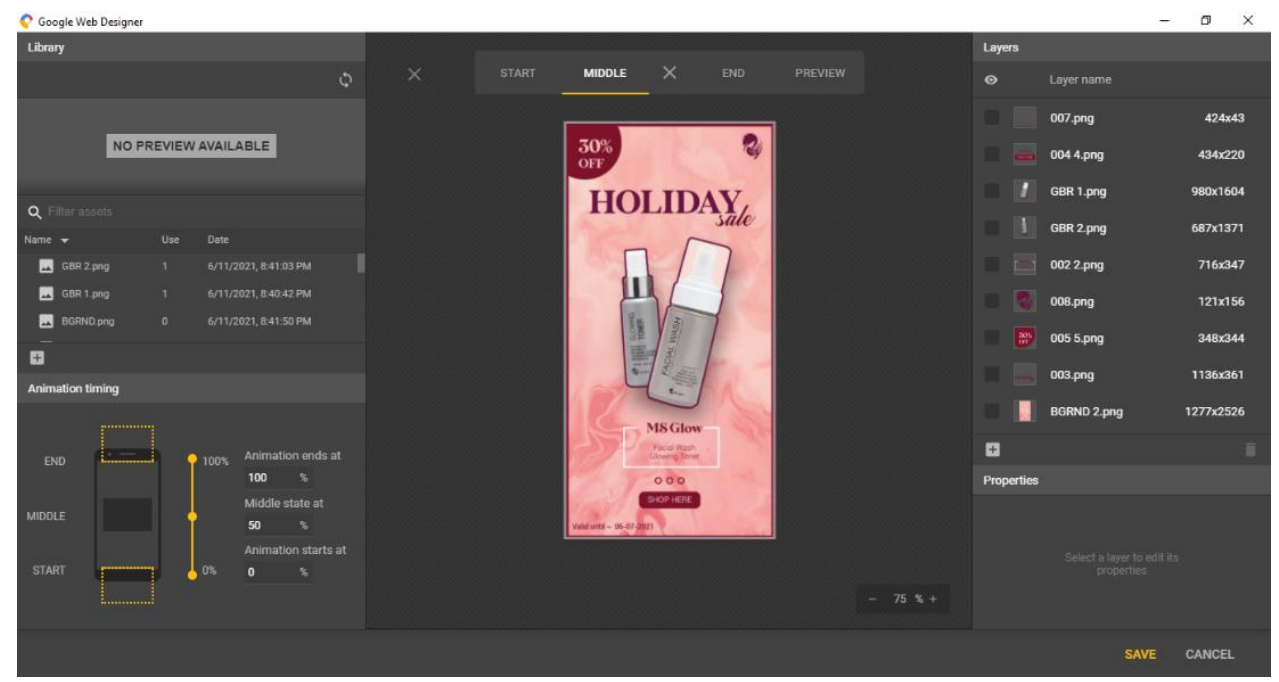

Gambar 4. Proses Pembuatan Iklan Web Mobile MSGlow di Google Web Designer 


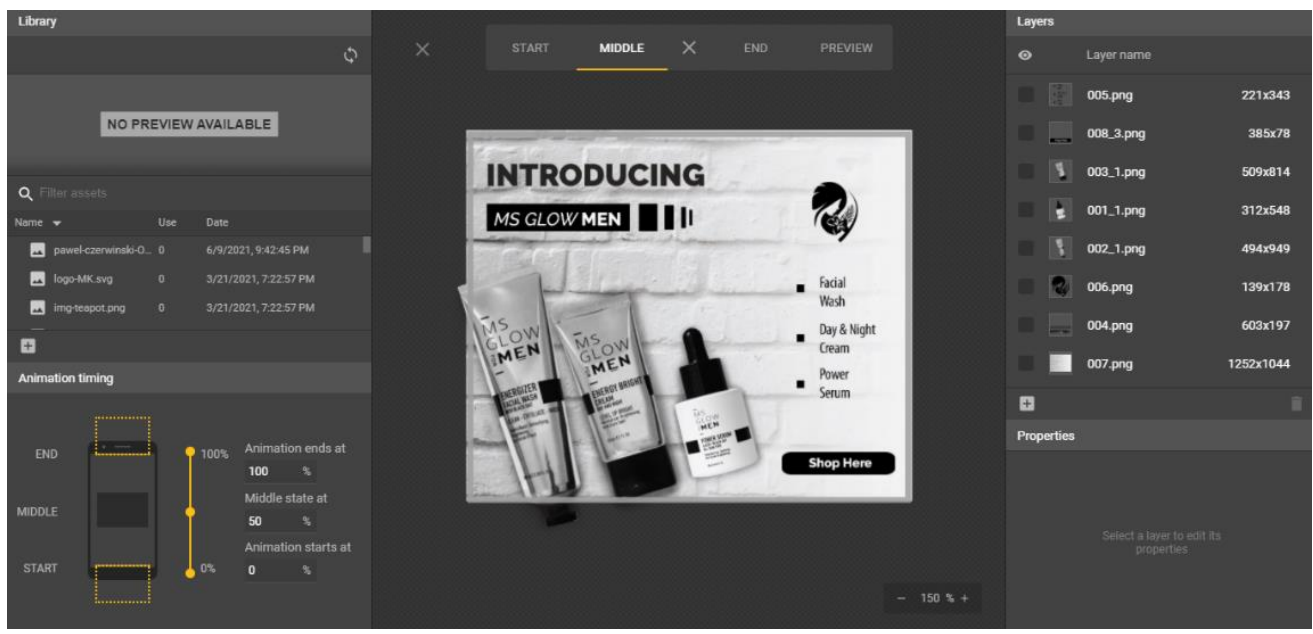

Gambar 5. Proses Pembuatan Iklan Web Mobile MSGlow Men di Google Web Designer

Gambar diatas merupakan hasil jadi Iklan Web berdasarkan 2 rancangan sketsa yang mana sudah dirangkai dan disusun sedemikian rupa menggunakan aplikasi Google Web Designer. Selanjutnya iklan web mobile tersebut akan dilihat bagaimana tampak iklan apabila dilihat di browser yang bisa dilihat di gambar dibawah ini

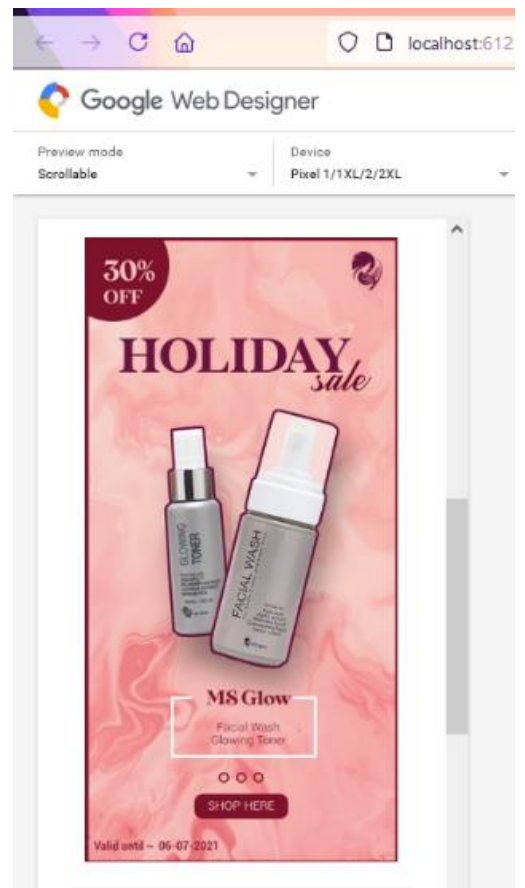

H

OS Type here to search

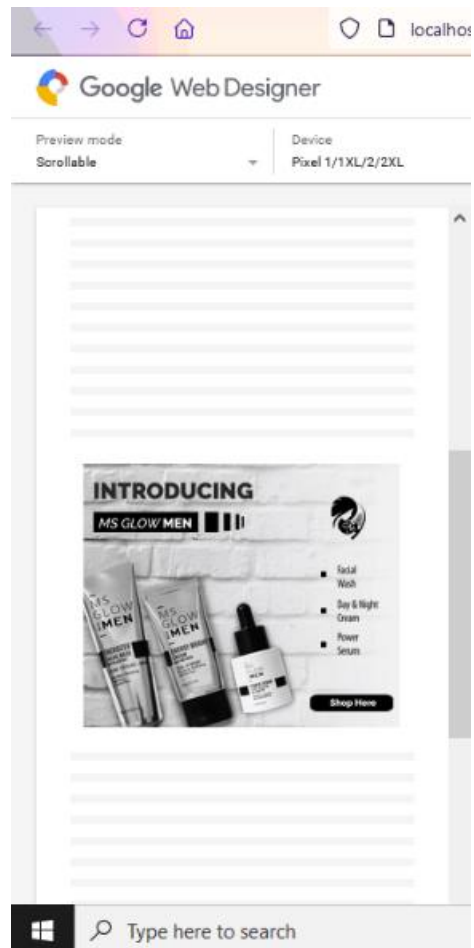

Gambar 6. Pengujian Prototype Iklan Web Mobile di Browser

Gambar diatas merupakan tahapan pengujian yang dilakukan oleh peneliti bagaimana iklan web mobile akan terlihat di browser menggunakan format yang mana komponen - komponen iklan akan bergerak apabila web di geser keatas maupun kebawah.

Rancang Bangun Iklan Web Mobile MS Glow Menggunakan Google Web Designer (Dhevin Kawistoro Ngabekti, Anung Rachman) 


\subsection{Validate}

Setelah selesai melakukan pengujian terhadap prototype iklan tahapan kali ini merupakan tahapan terakhir dimana peneliti melakukan pengujian dan Review menggunakan Google form kepada orang dewasa yang berusia 20 an yang mana pada usia ini termasuk dalam target pemasaran produk MSGlow. Survey ini menanyakan beberapa pertanyaan yaitu : Kejelasan penyampaian pesan, estetika komposisi visual, dan ketertarikan audiens dalam menanggapi iklan web tersebut. Gambar dibawah menunjukan hasil survey dari belasan orang yang sudah melihat dan memberikan penilaian berdasarkan pertanyaan yang diajukan melalui google form terhadap kedua prototype iklan web mobile MSGlow dan MSGlow Men.

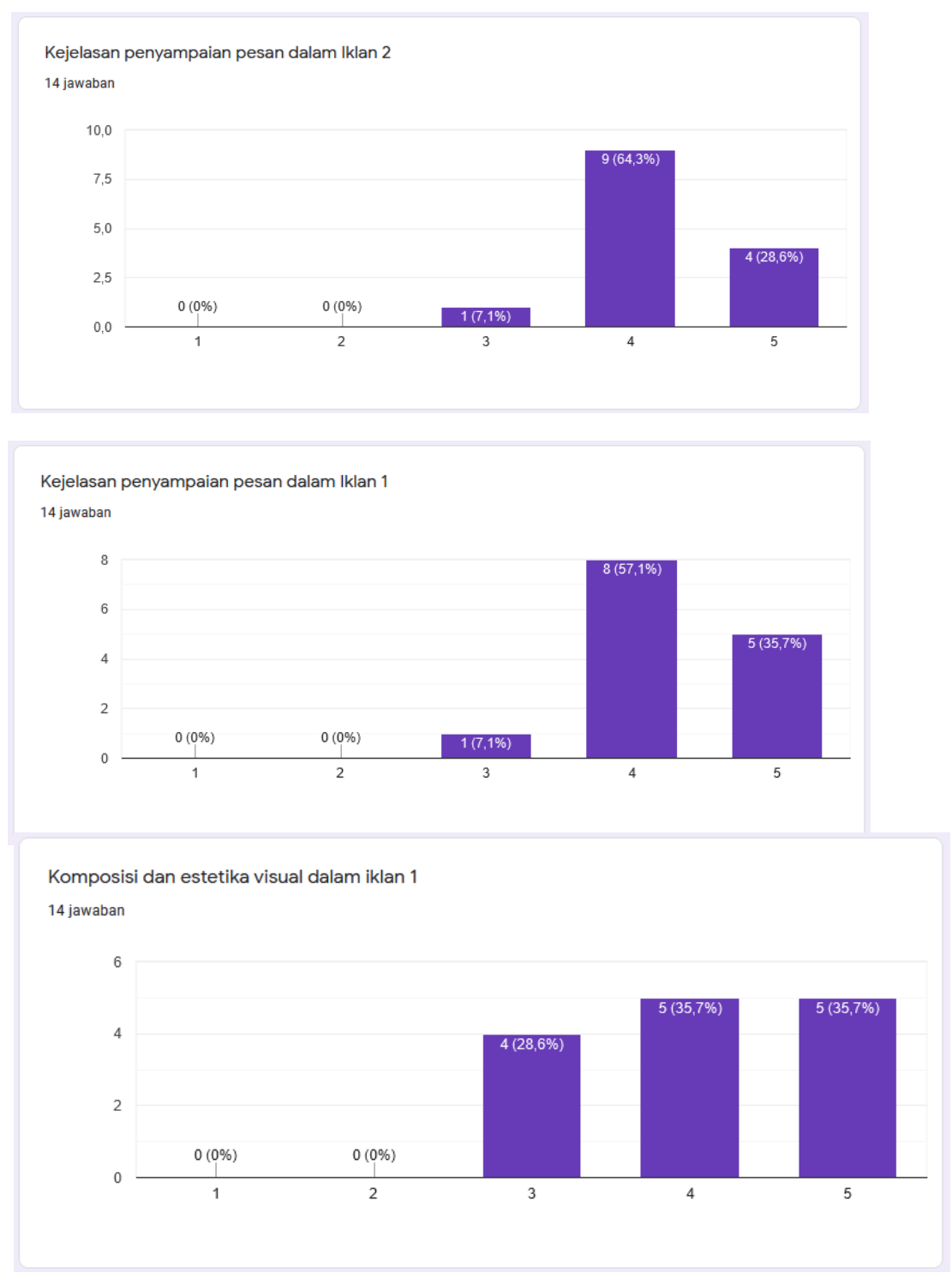


Komposisi dan estetika visual dalam iklan 2

14 jawaban

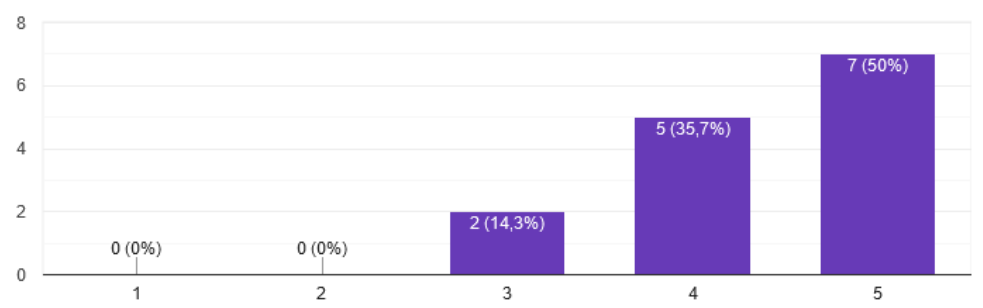

Jika anda menemui iklan ini apa yang akan anda lakukan

14 jawaban

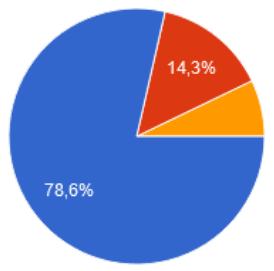

Tertarik dan melihat sebentar

Melewatinya begitu saja

gabisa saya pake adblock :

Apakah iklan ini lebih menarik daripada iklan2 yang biasa anda temui di internet

14 jawaban

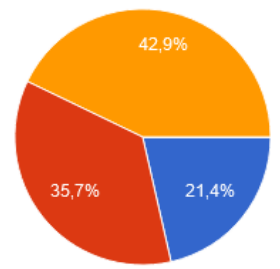

- Biasa saja

Mungkin

nope

\section{Gambar 7. Hasil Survey 2 Iklan Web Mobile}

Gambar diatas merupakan hasil survey mengenai review 2 prototype iklan web mobile. Dapat diambil kesimpulan bahwa, dalam segi penyampaian pesan, komposisi dan estetika, dan ketertarikan audiens terhadap prototype iklan MS Glow ini memiliki respon yang positif dan dapat diterima di kalangan audiens yang ditargetkan. 


\section{KESIMPULAN}

Berdasarkan hasil yang didapat mengenai pembuatan dan perancangan yang dilaporkan dalam bentuk paper penelitian ini dapat disimpulkan bahwa pembuatan iklan web mobile menggunakan aplikasi google web designer dapat memudahkan dan menghasilkan konten yang lebih bervariasi misalnya iklan berformat paralaks yang mana komponen iklan akan bergerak apabila audiens menscroll ke bawah. Dengan menggunakan aplikasi google web designer ini iklan yang dibuat akan menjadi lebih menarik karena adanya adanya fitur2 yang tidak ditawarkan oleh aplikasi lain dalam kaitannya dengan pembuatan iklan.

\section{DAFTAR PUSTAKA}

[1] Hakim, L., \& Vida, T. (2017). Sistem Informasi Promosi dan Pemasangan Jasa Iklan Berbayar Berbasis Web Mobile. Jusim, 2(1), 1-6.

[2] Kevin, A., Kusuma, C., Hertati, E., Fitriani, K. A., \& Wirawan, V. (2018). Analisa Tren Skin Care Natural Terhadap Preferensi Konsumen. Indonesian Business Review, 1(1), 130-142. https://doi.org/10.21632/ibr.1.1.130-142

[3] Mayangsari, E., \& Agustin, S. (2017). Pengaruh Iklan, Citra Merek Dan Kualitas Produk Terhadap Loyalitas Konsumen Menggunakan Produk Cantik Skin Care. Jurnal Ilmu Dan Riset Manajemen, 6(9), 19.

[4] Nabella, E. I. (2017). TINJAUAN SEMIOTIKA KOMUNIKASI VISUAL IKLAN CALEG SUPERMAN (Studi Kasus Iklan Politik Caleg Superman Pada Website Caleg Superman Tahun 2014). DeKaVe, 8(1), 11-18. https://doi.org/10.24821/dkv.v8i1.1545

[5] Nursalim. (2014). Iklan dan Implikasinya dalam Pendidikan. Kutubkhanah: Urnal Penelitian Sosial Keagamaan, 17(2), 255-264.

[6] Ramadan, R., Muslimah, A.-Z. H., \& Rokhmawati, R. I. (2019). Perancangan User Interface Aplikasi EzyPay menggunakan Metode Design Sprint (Studi Kasus PT. Arta Elektronik Indonesia). Jurnal Pengembangan Teknologi Informasi Dan Ilmu Komputer (J-PTIIK) Universitas Brawijaya, 3(9), 8831-8840.

[7] Susilo, M. (2018). Rancang Bangun Website Toko Online Menggunakan Metode Waterfall. InfoTekJar (Jurnal Nasional Informatika Dan Teknologi Jaringan), 2(2), 98-105. https://doi.org/10.30743/infotekjar.v2i2.171

[8] Tyas, A., \& Aryani, D. (2017). Efektivitas Iklan Digital Google Adsense. Jurnal Ekonomi Dan Bisnis, 20(1), 19-28. https://jurnal.unikal.ac.id/index.php/jebi/article/view/6 